\title{
A STUDY ON THE ASPECTS OF EUROCENTRISM AND DIFFUSIONISM REPRESENTED IN FOREIGNERS' TRAVEL RECORDS ON KOREA IN EARLY 1900s ${ }^{1}$
}

\author{
Kang Sok CHO \\ Inha University \\ Center for Korean Studies \\ Incheon, South Korea \\ kscho@inha.ac.kr
}

\begin{abstract}
This paper deals with three different perspectives appeared in foreign visitors' records on Korea in 1900s. Jack London was a writer who wrote novels highly critical of American society based on progressivism. However, when his progressive perspective was adopted to report the political situation of Korea in 1904, he revealed a typical perspective of orientalism. He regarded Korea and ways of living in Korea as disgusting and 'uncivilized.'

Compared with Jack London's perspective, French poet Georges Ducrocq's book was rather favorable. He visited Korea in 1901 and he showed affectionate attitude toward Korea and its people. However, his travel report, Pauvre et Douce Coree, can be defined as representing aesthetic orientalism. He tried to make all the 'Korean things' seem beautiful and nice, but it is true that this kind of view can also conceal something concrete and specific. This perspective at once beautifies Korea and also conceals
\end{abstract}

1 This work was supported by the National Research Foundation of Korea(NRF) Grant funded by the Korean Government (MEST) (NRF-2007361-AM0013) 
the reality about Korea.

E. Burton Holmes was a traveler and he often used his 'motionpicture' machine to record things he witnessed while travelling around worldwide countries. So, his report (travelogue) and motion picture film on Korea written and made in 1901 was based on close observation and rather objective point of view. Nonetheless, he couldn't avoid the perspective of the colonizer's model of the world, in other words, geographical diffusionism of western culture.

Key words: the other, representation, progressivism, orientalism, aesthetic orientalism, travelogue, geographical diffusionism

\section{0세기 초반 외국인 여행기에 나타난 유럽중심주의와 전파론의 양상}

논문초록: 본고는 20세기 초반 한국(대한제국)을 방문한 3명의 외국 작가의 글을 검토한다. 잭 런던의 직선적 진보의식에 기초한 오리 엔탈리즘이 타자를 유럽(서구)중심의 기준에 맞춰 무한히 상대화하 면서 스스로의 우월성을 강조한다면 조르주 뒤크로의 심미적 오리 엔탈리즘은 타자의 구체적 상황과 갈등과 내적 변모 과정을 무화시 키는 정서적 태도에 의존함으로써 타자를 항구적 불변의 지위에 두 려한다. 그런가 하면 버튼 홈스는 사용하는 매체의 특징에 따라 객 관적 관찰자의 시점을 유지하려는 노력을 기울인다. 그러나 그 역 시 근대적 확산론의 전제를 수용하고 있다.

잭 런던의 편협한 진보주의와 조르주 뒤크로의 복고적이고 심미화된 오리엔탈리즘, 그리고 버튼 홈스의 객관적 태도와 그것의 이면에 놓인 근대적 확산의 시계는 20 세기 초 조선을 방문한 민간 인 외국인들의 시선을 전형적 구도로 보여준다고 하겠다.

주제어: 타자, 표상, 방문기, 오리엔탈리즘, 심미화, 근대적 확산

\section{STUDIUM NAD EUROCENTRYZMEM I DYFUZJONIZMEM W POŚWIĘCONYCH KOREI DZIENNIKACH ZAGRANICZNYCH PODRÓŻNIKÓW Z POCZĄTKU XX WIEKU}

Streszczenie: Ten artykuł dotyczy trzech różnych perspektyw jakie pojawiły się w dokumentach zagranicznych gości na temat Korei w początkach XX wieku. Jack London był pisarzem, który pisał powieści bardzo krytyczne w stosunku do społeczeństwa amerykańskiego. Gdy jednak w 1904 roku przyjęto jego postępową perspektywę, opisując sytuację polityczną w Korei, ujawnił on typowy pogląd orientalizmu. Uważał, że Korea i sposób życia Koreańczyków są obrzydliwe i ,niecywilizowane”. W porównaniu z punktem widzenia Jacka Londona, książka francuskiego poety Georgesa Ducrocqa przedstawiała Koreę raczej w korzystnym świetle. Odwiedził Koreę w 1901 roku i okazywał uczuciową postawę wobec Korei i jej 
mieszkańców. Jednak jego sprawozdanie z podróży, Pauvre et Douce Coree, można określić jako reprezentatywny orientalizm estetyczny. Starał się, by wszystkie „koreańskie sprawy” wydały się piękne i miłe, ale prawdą jest, że taki pogląd może ukryć coś konkretnego. Ta perspektywa od samego początku upiększa Koreę, a także w tym samym czasie ukrywa rzeczywisty obraz Korei. E. Burton Holmes był podróżnikiem i często używał swojego „aparatu fotograficznego" do nagrywania rzeczy, których był świadkiem podczas podróży po całym świecie. Tak więc jego reportaż (travelogue) i film fabularny o Korei z 1901 roku opierały się na ścisłej obserwacji i raczej obiektywnym punkcie widzenia. Niemniej jednak nie mógł on uniknąć perspektywy modelu kolonizatora świata, innymi słowy, geograficznego dyfuzjonizmu.

Słowa klucze: inność, reprezentatywność, postępowość, orientalizm, estetyczny orientalizm, dziennik z podróży, dyfuzjonizm geograficzny

\section{Introduction: How can we interpret 'otherness'?}

'The other (他者)' is an ambivalent object of desire and fear. In Strangers, Gods and Monsters, Richard Kearney shows how the human outlook on the world is formed by three figurative characteristics of strangers, gods and monsters. He shows how our basic fears and desires manifest themselves in the external world, especially we try to interpret otherness and represent 'the other.' Exactly in this context, we can say the Orient has been the other of modern western worlds (Kearney: 2002).

Stuart Hall asks "Where and what is 'the West'?" He argues "West" and "western" represent very complex ideas and have no simple or single meaning. Although these words, including the supposed counterparts "East", "eastern", may seem to be about matters of geography location, he premises that "the West" is a historical, not a geographical, construct. By "western", we usually mean the type of a society that is industrialized, urbanized, capitalist, secular, and modern. In conclusion, Stuart Hall argues that "the West" is also an idea, a concept. He says it provides a standard or model of comparison. Accordingly, non-western societies can be said be "close to" or "far away from" or "catching up with" the West. Also, it provides criteria of evaluation against which other societies are ranked and around which powerful positive and negative feelings 
cluster. In short, Stuart Hall argues that the concept or the idea of "the West" functions as an ideology (Hall: 1992).

Considering above explanations, how can we interpret otherness? We need to examine the foreigners travel records in early 1900s to explain three conspicuous aspects on Korea and to explain how "the Western" functions as a criterion, concept or an idea in their ways of viewing "the Orient."

\section{Young Socialist's Eurocentrism and Orientalism}

In 1904, American novelist and journalist Jack London (1876-1916) came to Korea as a newspaper correspondent to cover the RussoJapanese War. He arrived at Jemulpo (Incheon) after hours' sailing from Japan. Following Japanese army heading for Ping Yang, he wrote articles and reports based on what he had witnessed in Korea. Before examining his reports, we need to notice that he was a young socialist around the time he visited Korea. He wrote an essay, 'How I became a socialist' in 1905 . He had a strong faith in socialist revolution. The fact that he was a progressive writer eludes many things and gives a key to read his writings on Korea and Korean people. In that sense, we need to pay attention to a subtle matter. It was the feudalism of Korea and feudalistic attitudes of Korean people he couldn't stand and annoyed him most. Let's have a look at the passages from Jack London's reports.

The Korean has finer features, but the vital lack in his face is strength. He is soft and effeminate when compared with the strong breeds, and whatever strength has been his in the past has been worked out of him by centuries of corrupt government. $\mathrm{He}$ is certainly the most inefficient of human creatures, lacking all initiative and achievement, and the only thing in which he shines is the carrying of the burdens on his back. As a draught animal and packhorse he is a success. And yet, I am confined-ay, wiling to lay odds-that my own breed can beat him at his own game. (London1970: 44) 
In short, the first weeks of a white traveler on Korean soil are anything but pleasant. If he were a man of sensitive organization he would spend most of his time under compelling sway of two alternating desires. The first is to kill Koreans; the second is to commit suicide. Personally, I prefer the first. But, now consider myself fairly immune and have reasonable hopes of surviving the trip.

The Japanese may be the Britisher of the Orient, but he is still Asiatic. (London 1970: 47)

To Jack London, Korean people are regarded as the most inefficient and helpless even compared with the Japanese and the Chinese. It needs to be mentioned that his downcast eyes are based on Eurocentric view of the world. All the manners and customs are evaluated by the western criteria. He wrote Japan is more developed and civilized nation. It's because the Japanese people are closer to his own ideas of "the West than the Korean. However, his Eurocentrism and Orientalism were still working when it's the case of the comparison of Japan and "the West. Let's have another look at his 'reports.'

The Japanese resembles a precocious child who talks philosophy one moment, and the next moment is making mud pies. One moment he is acting with the wisdom of the West and the nest moment with the childishness of the East. (London 1970: 124)

Samir Amin defines the unconscious motto of Eurocentrism as just one sentence: Imitate 'the west', the best one of the possible worlds! (Amin: 2010) As a socialist, Jack London criticized obsolete and rigid social systems of the East Asian countries, but as a progressive writer, he adopted the linear model of development, which made Korea and other East Asian countries seem "far away from" or "catching up with" the West. What was important to Jack London was the distance and differences between Korea and the West.

\section{Aesthetic Orientalism}

Georges Ducrocq (1847-1927) was a French poet and diplomat. He visited Korea in 1901, and after he returned home, he wrote a book, 
Pauvre et douce Corée (1904), the poor and gentle Korea. Compared with Jack London's attitude, Georges Ducrocq's one is rather favorable to Korea. In his book, he often expressed affectionate attitude toward Korea and Korean people.

Above sunny thatched cottages, narrow courses where
pots breathe and winding alleys, rises a little blue cloud,
when a light breeze is blowing. It means there are
women keeping cooking fires from extinguishing. So
happiness is everywhere. (Ducrocq 2001: 68)

No one is rushing. The sun shines brightly a breeze blows lightly. Koreans are happy and carefree in this peaceful country. (Ducrocq 2001: 130)

The above passages show typical features of Georges Ducrocq's sentences. He depicts a sight first and then, as such, he describes the feeling and emotion of the people, mostly happiness.

Facial expressions reveal no anxiety, and they have thin dreamy eyes. Their behaviors shows carelessness and good nature. That's because they have been totally accustomed to their persistent poverty. So their disdain for modern life is easily noticed. They do not want to lose that tranquility. (Ducrocq 2001: 74)

We might ask, "Are they really happy or do they just look happy to him? That makes the big differences. Does 'disdain for modern life' belong to Korean people or Ducrocq himself? Georges Ducrocq's retrospective attitude is closely related to an "aesthetical view" of the world. Terry Eagleton argues that the term "aesthetic" in modern European ideas means the ideological model which resolves and simultaneously conceals the contradiction between the concrete and the abstract, and also between the particular and the universal (Eagleton: 1990). In that context, we can define Georges Ducrocqs' perspective as a sort of 'aesthetical orientalism.' Compared with Jack London's harsh reports, Georges Ducrocq's book leaves a favorable impression at first look, but it is involved with another problem. He tried to regard all the 'Korean things' as fine and beautiful, but it can be said that this kind of view might also conceal something specific and real. This perspective at once 
beautifies Korea and conceals the hard situation of Korea and adversity of ordinary Korean people during that period. It seems more evident when compared with a passage from Isabella S. Bird Bishop's book, Korea \& Her Neighbours (1898), which was written right after her visit to Korea.

There are innumerable peasant farmers who have gone on reducing their acreage of culture year by year, owing to the exactions and forced loans of magistrates and yang-bans, and who now only raise what will enable them to procure three meals a day. It is not wonderful that classes, whose manifest destiny is to be squeezed, should have sunk down to a dead level of indifference, inertia, apathy, and listlessness.

In spite of reforms, the Korean nation still consists of but two classes, the Robbers and the Robbed, - the official class recruited from the yang-ban, the licensed vampires of the country, and the Ha-in, literally "low men," a residuum of fully four-fifths of the population, whose raison d'être is to supply the blood for the vampires to suck. (Bishop 1898: 280281.)

Compared with Bishop's description, Georges Ducrocq's attitude can be more clearly explained. It beautifies but it misses. That's the way Terry Eagleton's definition of "the aesthetic" goes.

\section{Diffusionism and the Scopic Regime of Modernity}

Burton Holmes (1870-1958) was an American traveler, photographer and filmmaker. $\mathrm{He}$ travelled all around the world and took photographs and filmed what he observed. He was the first person to put all his records into documentary travel lectures. He invented the word, travelogues. He visited Korea in 1901 and filmed what he saw during his visit. After returning to America, He made travelogues on Korea named, Seoul, the capital of Korea.

Actually, he filmed the ordinary Korean people's life. Due to that, he was invited to the palace and could meet the King. 
He presented his motion picture at the court, and that's the first screening of the movie in Korean history.

Along with Isabella S. Bird Bishop's rigid realism, Burton Holmes's work is quite respectful. He was always trying to keep an unbiased, unprejudiced eye on what he was witnessing and filming. Especially, comparing with Jack London's reports and George Ducrocq's book, we can say that he kept objective eyes on things. However, his perspective also has blind spots.

Through that medieval arch (the West Gate of Seoul) run trolley-wires and tram car tracks, over it telegraph and telephone wires are festooned; for the spider of modern enterprise is spinning its web of steel about this dormant Oriental metropolis. But just as clanging, chunking car comes arrogantly bursting through the gate, an official sedan-chair, borne silently and with slow dignity in the opposite direction, tells us that the manners and methods of the Middle Ages still persist in the quaint city of Seoul despite the advent of electricity. Sharp indeed are contrasts. (Holmes 1908: 20-21)

"Through that medieval arch (the West Gate of Seoul) run trolley-wires and tram car tracks, over it telegraph and telephone wires are festooned; for the spider of modern enterprise is spinning its web of steel about this dormant Oriental metropolis. But just as clanging, chunking car comes arrogantly bursting through the gate, an official sedan-chair, borne silently and with slow dignity in the opposite direction, tells us that the manners and methods of the Middle Ages still persist in the quaint city of Seoul despite the advent of electricity. Sharp indeed are contrasts."

Quoted passage typically reveals 'diffusionism' based on the model of linear development of modernity. J.M. Blaut defines 'diffusionism' as followings.

When culture change takes place in a human community, that change can be the result of an invention that occurred within this community. Or it can be the result of a process in which the idea or its material effect (such as a tool, an art style, etc.) came into the community, having originated in some other community, in some 
other part of the landscape. The first sort of event is called "independent invention." The Second is called “diffusion.” (Blaut 1993: 11)

J.M. Blaut is arguing that diffusionists axiomatically accepts the Inside-Outside model, the notion that the world as a whole has one permanent center from which culture-changing ideas trend to originate, and a vast periphery that changes as a result (mainly) of diffusion from that single center. As quoted above, Burton Holmes is saying "modern enterprise is spinning its web of steel about this dormant Oriental metropolis." Also, he is saying, "the modernizing of Seoul is inevitable." (Holmes 1908: 35)

Diffussionists' belief is that the center (usually "the West") of the civilization naturally progresses and modernizes and it spreads its material and cultural effects to vast peripheral parts of the world. In that sense, we can argue that Burton Holmes' perspective can be regarded as typical diffusionist's one, although he is a good observer. Considering that he often used the expression "as in more civilized communities", we could ascertain the points explained above.

\section{Conclusion}

As we have discussed, Eurocentrism or diffusionism is not the matter of geography or location. As Stuart Hall pointed out, if "the West" is a conceptual construct, "the East" is also a construct. Even Korea in 21th century might sometimes be regarded as the right center of 'Eurocentrism in Asia.' Thus, we need to remember that the center and periphery of civilization or modernization is also a notion of construct. Civilizations don't develop in an upright linear order. Korea, as in other parts of the world, can no longer be considered as a dormant land of hermits. That's why we have to ask the same question as Samir Amin asked.

How can we move towards a non-(Euro)centric view of history and culture now? 
Kang Sok CHO: A Study on the Aspects of Eurocentrism ...

Bibliography

Amin, Samir. 2010. Eurocentrism Modernity, Religion, and Democracy: a Critique of Eurocentrism and Culturalism, Monthly Review Press.

Bishop, Isabella. S. Bird. 1898. Korea \& Her Neighbours, vol. 2, London; John Murray, Abemarle Street.

Blaut, James M. 1993. The Colonizer's Model of the World: Geographical Diffusionism and Eurocentric History, New York: The Guilford Publications.

Ducrocq, Georges. 1993. Pauvre et douce Corée, Zulma.

Ducrocq, Georges. 2001. The Poor and Gentle Korea (가련하고 정 다운 나라 조선), translated by Choi, Mikyoung, Noonbit.

Eagleton, Terry. 1990. "Modernism and Imperialism", Terry Eagleton, Fredrick Jameson, Edward W. Said. Nationalism, Colonialism, and Literature, University of Minnesota Press.

Hall, Stuart. 1992. "The West and the Rest : Discourse and Power", Formations of Modernity, S. Hall \& B. Gieben (ed.), Polity Press.

Holmes, Burton. 1908. Burton Holmes Travelogues-With Illustrations from Photographs By the Author: Seoul, the Capital of Korea, New York: The McClure Company.

Kearney, Richard. 2002. Gods and Monsters, Routledge.

London, Jack. 1970. Jack London Reports: War Correspondence, Sports Articles, and Miscellaneous Writings, King Hendricks and Irving Shepard (ed.), Doubleday \& Company, Inc., New York. 